\title{
NEGOTIATING SOUNDSCAPE: Practice and Regulation of Adzan in Indonesia
}

\author{
Siti Aliyuna Pratisti \\ International Relations Department, \\ Faculty of Social and Political Sciences of Universitas Padjadjaran \\ Email: aliyuna@unpad.ac.id
}

\begin{abstract}
This article explores the historical context of practice and regulation of Adzan in Indonesia. As historical underpinnings, this article will follow a structural timeline of post-independence Indonesia to the current development of the state's regulations of Adzan. To understand the social context of Adzan, Schafer's conception of Soundmark and Hirschkind's ethical soundscapes will be employed as theoretical framework to analyze how Indonesian (government and civil society) negotiates social tension caused by the use of loudspeaker in Indonesian mosques. Government regulations will be used as primary sources, while newspaper, journal and websites, provide additional information on the practice and regulations of Adzan in Indonesia. This article, however, will limit its study to the historical and social aspect of Adzan. Discussion on the theological aspect will not be covered by this article.
\end{abstract}

Keywords: ethical soundscapes, history of adzan, soundmark

\section{Abstrak}

Artikel ini membahas konteks historis dari praktik dan regulasi Adzan di Indonesia. Sebagai landasan sejarah, artikel ini akan mengikuti struktur kronologi Indonesia pasca kemerdekaan hingga perkembangan peraturan negara Adzan saat ini. Untuk memahami konteks sosial Adzan, konsepsi Schafer tentang Soundmark dan tata suara etis Hirschkind akan digunakan sebagai kerangka teoritis untuk menganalisis bagaimana Indonesia (pemerintah dan masyarakat sipil) merundingkan ketegangan sosial yang disebabkan oleh penggunaan loudspeaker di masjid-masjid di Indonesia. Peraturan pemerintah akan digunakan sebagai sumber utama, sedangkan surat kabar, jurnal dan website memberikan tambahan informasi tentang praktek dan peraturan Adzan di Indonesia. Artikel ini, bagaimanapun, akan membatasi kajiannya pada aspek sejarah dan sosial dari Adzan. Pembahasan tentang aspek teologis tidak akan tercakup dalam artikel ini.

Kata kunci: Soundscape Etis, Sejarah Adzan, Soundmark

\section{INTRODUCTION}

"It is He who made for you the night to rest therein and the day, giving sight. Indeed in that are signs for a people who listen." (Qur'an, I0: 67)
For Muslims in Indonesia or those who live in Muslim majority countries, the cacophony of Adzan is part of daily life. It repeats five times a day: before dawn (Subuh), noon (Zhuhur), late afternoon (Ashar), at dusk (Maghrib), and

I PhD Student at Indonesia Consortium for Religious Studies, Universitas Gadjah Mada 
early evening (Isya). It is positioned among the mandatory ${ }^{2}$ practice of Islamic ritual and served as microcosm beliefs essentials to Muslim's faith (Al-Jaziri, 2004). Nasr in his work on Islamic art (I987) mentioned that Adzan (sound) is an extension of a mosque (place) which constitutes spiritual consciousness that very substance to human existence. Frembgen (20I2) also mentioned another function of Adzan in celebration of a newborn baby and the Shi'ite Ashura processions. Further, Nasr noted a significant standing of Adzan in his statement on Islam and music: "along with the Noble Quran, Adzan chanting is the most nourishing of all music for the soul of the people of faith" (Nasr, 1987). In a similar vein with Nasr earlier notion, Schafer (I994) compares two marks in the Muslim community: the landmark (mosque) and the soundmark ${ }^{3}$ (Adzan). Both, according to Schafer, are the icons of Muslim's social identity ${ }^{4}$. Without any doubt, Adzan is sacred for Muslim as a timely guide to spiritual reorientation (Arab, 20I7).

The practice of Adzan, however, cannot be isolated as one's spiritual experience as it also touches the social dimension. In this context, Adzan discovers a new meaning of becoming a social border and a marker of a community (Lee, 2003). The problem arises when different religious communities shared the same soundscape; while the meaning of Adzan is sacred for Muslim, it can turn out to be noise pollution for others. Indonesia experienced a bitter episode of such social friction in 2016, when Meliana, a residence of Tanjung Balai, North Sumatera, complained about the loud voice of Adzan. Then, she was charged with blasphemy law and

$2 \quad$ Adzan is mandatory or strongly suggested sunnah (sunnah muakad), or according to Imam Hambali, Adzan is compulsory with exceptional condition (fardhu kifayah), such as when someone travel or lives in nondominance muslim countries (Al-Jaziri, 2004)

3 Another definition of soundmark defined by Weiner (20I4), which, like landmarks "demarcate emotional boundaries for distinct communities but do so aurally rather than visually".

4 Schafer (I994) also mentioned that the Muslim acoustic line is "the area over which the muadzin voice can be heard as he announces the call to prayer from the minaret". Somehow the line has substantial redefinition since mosques apply loudspeaker for performing Adzan. sentenced for eighteen months based on articles I56 and 156a of the Criminal Code (Tehusijarana and Gunawan, 20I8). Before Tanjung Balai case, there is similar protest arise in Jakarta in 2007 and again, in 2013, when people who lived near Gereja Damai Kristus protesting the bell sound and symbols displayed by the Church. Fortunately, there were no casualties as Ustad Jufri (local Ulama) and later in 2013, Joko Widodo (Jakarta governor at that time) manage to push a peaceful negotiation (Tuasikal, 20I4). Religious identities marker in a shared soundscape, such as Adzan and Church's Bells, are tension-prone border. The Meliana case culminates social friction pertaining issues of Adzan that consistently contested in Indonesia religious public sphere; a debate which defined by Asad (2003) as constituted by memories and aspiration that articulate whether in fear or hope.

Religious expression, such as Adzan, Church's Bell or Tri Sandhya Mantra ${ }^{5}$, has been widely discussed, mainly from the perspective of anthropology and social politics (Dijk, 20I4; Geertz, I97I; Widjojoatmodjo, I942). The historical study of Adzan in particular, despite still limited to a partial timeline, provides valuable insights to the practice of Adzan overtime. In an attempt to add a piece of historical discourse on Adzan, this article aims to explore the practice and regulations of Adzan in Indonesia. To frame and limit the scope of discussion, research questions are formulated as follow: (I) How did Adzan shape the Islamic soundscape in Indonesia?; (2) How does technological development alter the practice of Adzan in Indonesia?; and (3) How is the practice of Adzan regulates over time and what are the implications?. As for time structure, this article will focus on Adzan public discourse from the early independence to the recent development of the blasphemy case in North Sumatera.

\section{HISTORICAL UNDERPINNINGS}

This article employs a systematic method of history (Munslow, 2012) to explore the practice

5 See Hynson (20I7) in $4^{\text {th }}$ Symposium: The ICTM Study Group on Performing Arts Of Southeast Asia, School of the Arts, Universiti Sains Malaysia 
and regulations of Adzan in Indonesia. The focus of this study is based on two reasoning: (a) as a state of the art of study on the history of religions, particularly in Southeast Asia; and (b) to explore the historical context of practice and regulation of Adzan in Indonesia. To provide a clear description of the topic, historical materials that underpin the practice of Adzan should be constructed. On this regard, Pancasila as the basic principles of Indonesia, need to be revisited to understand the background of religious practice in Indonesia. Pancasila invokes monotheism of Islam, Christian, Buddhist, and Hindu-which stated as the first of its five principles.

Supported by A Article 29 of I945 Constitution (Undang-undang Dasar 1945) which regulates religious freedom in Indonesia, the first Pancasila principle has created solutions for the new multicultural nation, despite the elite Muslim dominance (Aragon, 2000). The Ministry of Religious Affairs of Indonesia, at that time under the name of Departemen Agama (Department of Religion), established soon afterwards in 1946 to enforce the principle as suggested by Badan Pekerja Komite Nasional Pusat; (Picard, 20or; Penetapan Pemerintah, I946). Regulation on religious expression, including the practice of Adzan, is under the authority of the Department of Religion (now Ministry of Religious Affairs). Listed below are regulations related to religious freedom, antiblasphemy law and guideline on the practice of Adzan in Indonesia.

\begin{tabular}{ll}
\hline No. & List of Primary Sources \\
\hline 1. & Article 29 of the 1945 Constitution (Undang- \\
& undang Dasar 1945) \\
\hline 2. & Regulation on Radio Broadcast for Dakwah and \\
& Early Morning Sermon (Keputusan Menteri \\
& Agama Nomor 44 Tahun 1978; Instruksi Menteri \\
& Agama No. 9 Tahun 1978; and Surat Edaran No. \\
& 3 Tahun 1978) \\
\hline 3. & Instruction for Loudspeaker Operational \\
& Standard in Mosques (Instruksi Direktur \\
& Jenderal Bimbingan Masyarakat Islam No. \\
& Kep/D/101/1978) \\
\hline R. & Regulation for Religious Harmony (Peraturan \\
& Bersama (PBM) Menteri Agama dan Menteri \\
& dalam Negeri No. 9/2006 dan No. 8/2006) \\
\hline 5. & Restated on the Instruction Loudspeaker Opera- \\
& tional Standard in Mosques (Edaran Dirjen Bi- \\
& mas Islam No. B.3940/DJ.III/HK.00.07/08/2018) \\
\hline
\end{tabular}

Source: various literature study

Primary sources will be combined with secondary literature, such as Fatwas from Islamic scholars, academic journals and newspaper articles that have a direct or indirect relation to the topic of practice and regulation of Adzan in Indonesia. While the conceptions of soundmark (Schafer, 1994) and ethical soundscapes (Hirschkind, 2006) will be employed as a theoretical framework to be analyzed with the related data on the practice and regulations of Adzan in Indonesia. This article, however, will not cover the Islamic conduct of Adzan (fiqh), as it discusses under the study of theology.

\section{ISLAMIC SOUNDSCAPE: SHAPING MEMORY AND AUDITORY LITERACY}

In describing Indonesia Islamic soundscape, Rasmussen (20I7) highlighted two specific characters of music and its orality. She argued:

"...on the importance of sound and of hearing as a methodology for knowledge; on the existence of the text as one that is sounded in recitation and not merely read; and on transformative experiences through movement and sound as it is heard, spoken, recited, chanted, sung, shouted, and played (either on instruments or through speakers) that are central to the experience of the religion, from the mundane repetition of daily ritual, to the quest for and encounter with states of elation, ecstasy, rapture, trance, and union with the divine".

In Rasmussen view, "mundane repetition of daily ritual", such as Adzan, performs as central key in shaping religious experience. It shared the same opinion with Kapchan (2007) who explained that soundscapes are shaped from the creation of structural perception from listening and developing memory and auditory literacy. The repetitive practice of Adzan performed the exact function in shaping the auditory memory of Islamic soundscapes. The first Adzan is shouted (or rather, recited) by Bilal ibn Rabbah as instructed by Prophet Muhammad in the second year of Hijriah ${ }^{6}$. Since then, Adzan is an

6 See the encyclopedia of Islam (Brill Online, 20I4) which depicts the instruction given by Prophet Muhammad to Bilal ibn Rabbah as the first muadzin (the person in charge of the call for prayer). Imam Bukhari describe that before reaching agreement on how to recite Adzan, several methods is suggested, from bell ringing to fire as light signal, but then the jamaah is agreed upon loud human voice to differentiate from Jewish (horn) and Christian (bell) call for prayer. 
everyday experience of Muslim life and creates a sense of sound identity-or in Schafer's word: a soundmark (Schafer, 1994).

Adzan was introduced to Nusantara along with the coming of Islam. Among the oldest script which mentioned the practice of Adzan is the Hikajat Raja-raja Pasai (History of Princess of Pasai) (Bastin and Roolvink in Drewes, I968). In the Hikajat, Merah Silu (or known as Sultan Malikussaleh of Samudera Pasai), once dreamt that Prophet Muhammad spat in his mouth and chanting Adzan ${ }^{8}$ in his ear, and miraculously, Merah Silu can recite Qur'an without prior learning. The later practice of Adzan is in line with the spreading Islam in Nusantara. In Rasmussen (2017), the early Islamic soundscapes in Indonesia is formed in the village's surau (small mosque), which are used for prayer and religious gathering. Arab (20I7) explained a contextual practice of Adzan in Indonesia under Dutch colonized "where the role of Islam was generally downplayed, thus colonial interest in the Adzan was minimal if present at all". Arab also compared the French with Dutch colonies in term of the civilizing mission. While the previous was explicit; the later showed a more moderate approach ${ }^{9}$. The minimum restriction from Dutch ${ }^{\mathrm{IO}}$, gave an opportunity for identity construction, including soundscapes identity.

The Islamic soundscapes in Southeast Asia, including Indonesia, has another distinctive instrument that differentiates it from other Muslim countries. Burhanudin and Dijk (2013) explored the instrument of Bedug (wooden drum with animal leather) and Kentungan (tree trunks), are also used to announce prayer times.

$7 \quad$ The Hikajat is believed to be written in I4 CE, while Sultan Malikussaleh formed the fisrt Muslim Sultanate in Nusantara, the Samudera Pasai, in 1267 CE.

8 Other version, however, mention it was Basmalah, not the adzan (Widjojoatmodjo, I942)

9 Regulation for Commissaries-General article 97: "the prayer meetings of all religions in the Netherlands Indies have the protection of the High Government provided, that this prayer meeting is of no danger for public order" (Widjojoatmodjo, I942)

Io Arab (2017) also translates a Dutch newspaper in colonial time: "The imam delivers his khutba (sermon) on Friday. Furthermore, each mosque has a muadzin that calls to prayer. . . For the very indispensable good relation between Dutchmen and Indonesians it is necessary that Islam and its professors are in no way disturbed".
The two instruments have a long tradition in Nusantara date back to the earlier tradition of Hindu and also reflect Chinese influence. As mentioned by Dutch surgeon W. Schouten (Breet in Burhanudin and Dijk, 2013), he found Bedug in Ternate mosques when he visited the Sultanate in I659. Muslim scholar, however, shared different opinion regarding the use of Bedug and Kentungan.

Nahdatul Ulama (NU), one of the largest Muslim organizations in Indonesia, stated that the two instruments are a cultural heritage that needs to be valued (Mahfudh, 2oII). While Muhammadiyah, another leading Muslim organization, emphasis more on the relevant use of Bedug and Kentungan ${ }^{\text {II }}$ (Abdurrahman, 2007). Another dissenting opinion was voiced by the Muslim organization of Persatuan Islam (the Islamic Union) which also discuss specifically on the use of Bedug and Kentungan. The fatwa from the Persatuan Islam was published in Journal Pembela Islam ${ }^{12}$ as follow (Kaptein, 2004):

Question: Tree trunks, and drums are used in the local prayer houses to gather the people for the prayer. After this, they are summoned again with the call to prayer (adzan). What is your legal judgment about this?

Answer: Tree trunks and drums in order to gather the people for prayer were never been used by the Prophet or by his Companions. It is even known that some Companions put forward various ways of calling to gather the people for the prayer, but all of those were rejected by the Prophet.

Despite the varied perspective, there was a valid evidence that in some area (especially in rural area), Bedug and Kentungan ${ }^{13}$ also shaped the Islamic soundscapes of Indonesia (Burhanudin and Dijk, 20I3).

II Majelis Tarjih Muhammadiyah mentioned that Be$d u g$ and Kentungan no longer needed since it function is replaced by loudspeaker.

I2 Jurnal Pembela Islam (The Defender of Islam) active during period of 1929 to 1935

I3 Bedug and Kentungan performed essential role to signified the time of prayer before the use of loudspeaker. It can reaches further than human voice, and at that time, Adzan its recite after the jamaah gathered (Lee, 2003). 
The Muadzin performance of Adzan is another essential element in Islamic soundscapes. There are many ways in performing Adzan as practiced by the four great Imams of Islam: Imam Hanafi, Imam Hambali, Imam Shafi'i, and Imam Maliki ${ }^{14}$. In Indonesia, particularly, Adzan developed into seven main melodies (langgam): Nahawand, Rost, Bayati, Shoba, Jiharkah, Hijaz, and Shika. However, a more syncretic form of Adzan can be found in many parts of Indonesia when it merges with traditional aesthetic expression. Al Bakri, Mallah and Nuserat (2019) noted the origin of the varieties performance of Adzan as follow:

"The fixed method of pronunciation for the phrases of Adhan and the way they should be sequenced, repeated, and divided by specific breaths is called Tarjee. However, music performance lay on loose guidelines, passed by oral tradition, and manipulated by free variables flying under the radar of references. This mode of verbal transition for performative skills and methods can be described as a powerful encoding of primordial emotion, transmission of venerable precious expertise, and free aesthetic expression".

Albeit the fact that Islam holds the unchanging words and principles for Adzan, characteristic of Adzan performances is rather changing over time and places. Thus, the universality of Adzan reflects the cosmopolitan view of Islam ${ }^{\text {I5 }}$ which translated into different cultures and creates a diversity of soundscapes. Yet, there is another aspect that alters the practice of Adzan: technology-which will be further elaborated in the next part of this article.

I4 Despite the difference, Imam Hanafi mentioned that the fixed method is refer to how Bilal ibn Rabbah practice of Adzan called tarjee (Al Bakri, Mallah and Nuserat, 20I9)

I5 Widjojoatmodjo (I942) portrays how Indonesian Muslim encounter with the Arab and Pan-Islamism during Dutch colonial mainly accommodate by the conduct of Muslim pilgrims (Hajj). He also noted the universality of Islam as follow: "But no matter how indifferent the Indonesian Moslem may become to- wards the daily duties of Islam and towards the higher ideals of his fellow-Moslems, he will call the Adzan (call to the salaats) in the ears of his newly-born babies, and as he is placed in his grave the same Adzan will be sung! Thus he will continue to be born and to die a good Moslem".

\section{AMPLIFYING ISLAM: THE TECHNORITUAL OF ADZAN}

The history of Adzan flows in a similar vein with the development of technology. Yet, an article published by De Hofstad, on 26 February I9I8, cannot be ignored. The article is not reporting per se on the practice of Adzan nor the development of technology but on the performance of Javanese Rhapsody along with the Arabian Song of Death and Mohammedan Prayer held in the Diligentia concert Hall, The Hague, 25 January I905. Dijk (2014) describes the performance as the first display of the sound of Adzan to the Dutch audience. In the Arabian Song of Death, Adzan is performed in a more serene tone as a farewell song for the departed. The performance, however, accompanies by a piano instrument which is different from the actual practice.

Adzan originally recited by using loud human voice with certain melodies and technical breathing. As technology evolves, radio and television broadcast, also the use of loudspeaker in mosques, are inherent to the practice of Adzan, particularly in Muslim countries. Indonesia history recorded broadcast of Adzan in 1936 by Nederlandsch-Indische RadioOmroepmaatschappij (NIROM) (Yampolsky, 2013). In broadcasting Adzan, NIROM used gramophone instead of Muadzin voice; the broadcast can be reached in partial areas of Surabaya, Central Java and Bandung. Further, Yampolsky (20I3) mention that in I937, NIROM decided to broadcast Adzan once a week as a symbol of religious calling. The decision made due to time difference that sparked public debate regarding the broadcast of Adzan at that time.

The use of loudspeaker for Adzan, on the other hand, has been practiced since I930. The first loudspeaker is installed in Surakarta Mosques and used to amplify Adzan to its surrounding (Dijk, 2007). After independence, it was difficult to trace which mosques were the first to install loudspeaker, but Burhanudin and Dijk (2013) predicted that in I950, many mosques started to use the loudspeaker for Adzan. The prediction resulted from the public debate on 
amplifying Adzan which widely discussed in the I950s. In contrast to the massive use of loudspeaker, Bedug and Kentungan are slowly replaced. Husain (20I7) mentioned that nowadays, Bedug and Kentungan are a cultural symbol in mosques with specific affiliation to Nahdatul Ulama (NU).

Adzan also is broadcasted through national television at sunset (Adzan Maghrib). Another media that additionally used in the practice of Adzan is a mobile phone application which can be automatically set for prayer time. Arab (2017) mentioned two crucial reasons for the new technological development: to reach the Muslim community that located beyond the soundscapes of Islam, also to reduce negative response toward the loud amplifying of Adzan. The using of mobile phone application instead of loudspeaker is relevant to the Muslim community who are living in non-dominance Muslim countries. In Indonesia, however, the replacement (from loudspeaker to mobile phone application) will mean redefining Islamic community. As Bourdieu (I977) stated that: the change in conventional practice, also significantly transforms and constitutes the habitus traditionally framed by it. Daring analysis on religious communication is made by Millie (2017), who noted that Islamic norms and practices amongst Indonesian Muslim are integral to people's understanding of their national public spheres. Bourdieu's point resonates with Millie's observation, that the possibility of ethical soundscape is attainable within the changing medium of Adzan provided by technology.

\section{REGULATING ADZAN IN INDONESIA}

Discourse on Adzan in Indonesia is associated not only in the internal Muslim community but also public in general. The shared soundscapes in rural and urban areas between different ethnic and religious groups demand a clear regulation in sound production. In regard to managing sound production in Indonesia's religious public sphere, the Ministry of Religious Affairs published instructions to regulate the uses of loudspeaker in mosques. The instruction is based on previous regulations regarding religious freedom and public sermon, including: (I) Article 29 of the Constitution (Undang-undang Dasar 1945) which guarantee religious freedom for every citizen and freedom to perform religious rituals; (2) Regulation No. 44 I978 from the Ministry of Religious Affairs on Radio Broadcast for Sermon; (3) Instruction No. 9 I 978 from the Ministry of Religious Affairs on the procedure for Mubaligh to Perform Sermon via Radio Broadcast; and (4) Circular letter from the Ministry of Religious Affairs on Broadcasting Sermon on Radio.

Based on the mentioned regulations, the Ministry of Religious Affair issued an Instruction from Islamic Community Development (Instruksi Bina Masyarakat Islam) Kep/D/IoI/I978 on the operational standard for loudspeaker use in mosques dated I7 July I978. Main points from the instruction are as follow:

I. Loudspeaker is used for Dakwah and performing Adzan, however, negative response is found due to the improper use of loudspeaker

2. District body of the Ministry of Religious Affairs is obligate to provide guidance on the operational standard in using the loudspeaker to the mosque administrator

3. Loudspeaker speaker should be used wisely in order to not disturbe he surrounding

4. Professional maintenance is applied as basic standard to prevent cluttered noise that can disturbe the surrounding

5. External loudspeaker is used only for Adzan with certain limit of time (fifteen minutes before Subuh and Dhuhur, five minutes before Ashar, Magrib and Isya); External loudspeaker can also be used for celebration of Idul Fitri and Idul Adha.

6. Other rituals, such as shalat, khutbah and prayers, only allow to be amplified using internal speaker.

The instruction also covers details on the responsibility of Muadzin, who has to ensure their capacity in a good recital of Adzan; also covers the use of cassette for Qur'an recital that has to be in a good condition. 
However, the 1978 instruction did not touch issue on the limitation of loudspeaker volume. The lack of clear regulation for loudspeaker volume has caused social friction which culminates in the Meliana case in 2016. In the court hearing, Meliana mentioned that she's only asked to turn down the volume, but she's, then, charge for disrespecting Adzan (Tehusijarana and Gunawan, 2018). In response to the Meliana case, the Ministry of Foreign Affairs issued a circular letter No. B.3940/ DJ.III/HK.0o.07/08/2018 restating the 1978 loudspeaker instruction which covers four points:

I. To copy the (Instruksi Bina Masyarakat Islam) Kep/D/roi/r978 and share it to mosques and mushalla administrator, leader of Muslim organizations, majlis taklim (Muslim gathering) organizer, and all religious institutions;

2. To explain the (Instruksi Bina Masyarakat Islam) Kep/D/IoI/I978 and share it to mosques and mushalla administrator, leader of Muslim organizations, majlis taklim (Muslim gathering) organizer, and all religious institutions;

3. To use the (Instruksi Bina Masyarakat Islam) Kep/D/Ior/I978 as study material; and

4. To share the (Instruksi Bina Masyarakat Islam) Kep/D/ror/r978 in social media in respective manner.

The unclear regulation on loudspeaker volume indicates that there are still aspects to be considered in applying technology for religious rituals. Indonesia, at this point, still struggles with the negative excess of technology that triggers social anxiety.

\section{NEGOTIATING SOUNDMARK OF IDENTITY}

Abdurrahman Wahid (I982) had represented the internal voice from Muslim community with clear-cut self-critics:

The Prophet Muhammad said, the obligation (religion) was erased from three kinds of people: those who were crazy (until they were cured), those who were drunk (until they came to their senses), and those who slept (until they woke up). As long as he is sleeping, a person is not burdened with any obligations. Allah Himself has provided a "mechanism" to regulate the wake and sleep of humans. in the form of our own body metabolism. So there is no reason to wake a sleeping person to pray - unless there is a valid cause according to religion, it is known as' illat.... Common sense is sufficient as a basis for reconsidering loud voice "wisdom" in the middle of the night - especially if preceded by prolonged tarhim and recitation of the Koran. What is more, if the technology that calls out loud in the blind world only uses tapes! While the mosque administrators themselves sleep peacefully at home.

Wahid's notion indicates that public discourse on the use of loudspeaker is still far from being finalized ${ }^{16}$. One of the problems lies in the nature of soundscapes: it shared equally, yet it also imposed evenly. Kapchan (20I7) ideas on claiming soundscapes, reflects the Islamic use of Adzan in Indonesia. Here's an analogy: Dakwah (spreading of Islam) required tactics, and "every tactical listening listens for dissensus and thus becomes itself dissensual. "Wahid, and many other Islamic scholars who shared his view ${ }^{17}$, declined to use the loudspeaker to define the Islam community; however, those who inclined also have their reasons.

Other countries, interestingly, shared similar tension as experienced by Indonesia. Egypt and India, according to Hirschkind (2006), have the most violent tension related to the use of cassette recorders and loudspeakers in religious rituals as routinely complained as "assault on the ears". Many Muslim countries (such as Indonesia and Egypt) drove by pan-Islamism in reclaiming the soundscapes; while India, the

I6 In Yampolsky (2013), debate on Adzan also occurred during Dutch Colonized. At the time, Muslim are protest to the inaccurate time of Adzan broadcast in NIROM. Henry James, represent NIROM rephrase as follow: "NIROM could not win in the fight over the adzan, its efforts were doomed by a general inability of political leaders in the Dutch East Indies to reconcile either the progressive Dutch vision of the colony or the nationalists' dream of an independent Indonesia with the reality of the archipelago's enormous diversity and its competing ethnic, religious, and regional interests".

I7 In one of his poem, Mustafa Bisri mentioned: "Kau bilang Tuhan sangat dekat, namun kau sendiri memanggilnya dengan pengeras suara setiap saat" 
strong religious affiliation of many different communities, struggled in reclaiming the cities soundscapes. Another striving for acoustic identity is faced by the Muslim community in Europe for a different reason: to marke Muslim as part of the European community (Arab, 20I7). Hirschkind (2006), however, noted that the problem of ethical soundscapes is: "The challenge moral consciousness, especially in light of the current danger of a world increasingly polarized along religious lines". Hirschkind's note on ethical soundscape, however, facing a grimed reality when it was reflected to the present mode of Islam in Indonesia. As religious conservatism arises due to political clientism which was influenced by religious identity (Siregar, 2020), a space for inclusive public sphere and ethical soundscape seems to be diminished. Rather than embracing the diversity of sound, a trending demand for public sermon and public recital of Qur'an (mainly using the Mosque's speaker) is louder than ever (Millie, 20I7).

However, this does not mean that religious harmony is far from our reality. A meaningful step has been taken in dealing with the tension of acoustic identity. In 2006, an attempt to actualize multicultural harmony is brought into an open discussion and as the resulted, the Regulation for Religious Harmony is published (Peraturan Bersama (PBM) Menteri Agama dan Menteri dalam Negeri No. 9/2006 dan No. $8 / 2006$ ). The regulations highlight several pressing issues such as: promoting tolerance, procedure on establishing the house of worship (rumah ibadah), and the establishment of Forum Kerukunan Umat Beragama (Religious Harmony Forum). Despite the fact that the 2006 regulations did not specifically refer to the issues of acoustic identity and ethical soundscapes, Forum Kerukunan Umat Beragama provides an open religious public sphere to reduce the tension between religious communities. However, tolerance from the 2006 regulations is denied by multiple cases related to religious violence occurred in Indonesia ${ }^{18}$. Thus to attain an ethical soundscape, we have to reflect upon

I8 Meliana case is one example, others are: the burning of a Church in Aceh Singkil, conflict in Tolikara also violence to religious minority (Shi'ite and Ahmadiyah) the moral consciousness and move beyond haereticus quietus (toleration of difference as long as it remained silent) (Forst, 2013), to an ethical sharing of soundscape identity.

\section{CONCLUSION}

The practice of Adzan is essential for every Muslim: as a call for prayer, for spiritual reorientation, or identity marker. However, in Indonesia, the sacred practice of Adzan is challenged by social tension caused by public dissenting opinion toward the used of loudspeaker in amplifying Adzan. The regulation pertaining to the practice of Adzan is issued in I978. However, the lack of detailed regulation on loudspeaker volume has raised another friction and debate in Indonesia religious public sphere. There is no additional regulation added in response to the case of Meliana in 20I6. Thus, the line for acoustic identity in Indonesia is still negotiated-not only between religious communities but also in terms of the government will to promote an ethical soundscape.

\section{REFERENCES}

Abdurrahman, A. (2007). Tanya Jawab Agama 4 Suara Muhammadiyah. Pustaka Pelajar.

Al-Jaziri, A. (2004). Al-Fiqh ala Madzahib al-Arba, Jilid I. Darul Hadist.

Arab, P. T. (20I7). Amplifying Islam in the European Soundscape. Bloomsbury Publishing Plc.

Aragon, L. V. (200o). Fields of the Lord: Animism, Christian Minorities, and State Development in Indonesia. University of Hawai'i Press.

Asad, T. (2003). Formations of the Secular: Christianity, Islam, Modernity. Stanford University Press.

Bourdieu, P. (1977). Outline of a Theory of Practice. Cambridge University Press.

Dijk, H. M. (20I4). Constant Van De Wall, A European-Javanese Composer. In E. Barendregt, B. \& Bogaerts (Ed.), Recollecting Resonances: Indonesian-Dutch Musical Encounters. BRILL.

Dijk, K. van. (2007). The Changing Contour of Mosques. In P. J. M. Nas (Ed.), The Past in the Present. Architecture in Indonesia (pp. 45-66). NAi Publishers and KITLV Press.

Drewes, G. W. J. (I968). New Light on the Coming of Islam to Indonesia? Bijdragen Tot de Taal-, Land-En Volkenkunde, I24(4), 433-459. 
Forst, R. (2013). Toleration in Conflict. Past and Present. Cambridge University Press.

Frembgen, J. W. (2012). The Horse of Imam Hoseyn: Notes on the Iconography of Shi'i Devotional Posters from Pakistan and India. In P. Khosronejad (Ed.), The Art and Material Culture of Iranian Shi'ism: Iconography and Religious Devotion in Shi'i Islam (pp. I79-I94). I. B. Tauris.

Geertz, C. (I97I). Islam Observed: Religious Development in Morocco and Indonesia. Phoenix Book.

Hirschkind, C. (2006). The Ethical Soundscape. Cassette Sermons and Islamic Counterpublics. Columbia University Press.

Husain, S. (20I7). Sejarah Masyarakat Islam Indonesia. Airlangga University Press.

Hynson, M. (20I7). The Tri Sandhya: Politics and Sound in A Balinese Dispaly of Religiousity. Proceedings of the 4th Symposium on Performing Arts of Southeast Asia.

Jajat Burhanudin and Kees van Dijk. (20I3). Islam in Indonesia. Amsterdam University Press.

Kapchan, D. (2007). Traveling Spirit Masters: Moroccan Gnawa Trance and Music in the Global Marketplace. Wesleyan University Press.

Kapchan, D. (20I7). Listening Acts: Witnessing the Pain (and Praise) of Others. In D. Kapchan (Ed.), Theorizing Sound Writing (pp. 277-293). Wesleyan University Press.

Kaptein, N. G. J. (2004). The Voice of the 'Ulamâ': Fatwas and Religious Authority in Indonesia. Archives de Sciences Sociales Des Religions, 49(I25), II5-I30.

Karina M. Tehusijarana and Apriadi Gunawan. (2018). The Meiliana Case: How a noise complaint resulted in an I8-month jail sentence. The Jakarta Post. https://www.thejakartapost. com/news/20I8/o8/23/the-meiliana-casehow-a-noise-complaint-resulted-in-anI8-month-jail-sentence.html

Lee, T. S. (2003). Technology and the Production of Islamic Space: The Call to Prayer in Singapore. In René T. A. Lysloff and Leslie \& Gay (Eds.), Music and Technoculture. Wesleyan University Press.

Mahfudh, S. (20II). Solusi Problematika Aktual Hukum Islam Keputusan Muktamar, Munas dan Konbes Nahdhatul Ulama (1926-20IO). Khalista.

Millie, J. (20I7). Hearing Allah's Call: Preaching and Performance in Indonesian Islam. Connell University Press.
Munslow, A. (2012). A History of History. Routledge.

Nasr, S. H. (1987). Islamic Art and Spirituality. State University of New York Press.

Penetapan Pemerintah No. I/S.D. 1946. On the establishment of Departemen Agama and Balai Pemuda yang menjadi bagian dari Departemen Sosial.

Picard, M. (200I). The Politics of Religion in Indonesia: Syncretism, Orthodoxy, and Religious Contention in Java and Bali. Routledge.

Rasmussen, A. (20I7). Women Out Loud: Religious Performance in Islamic Indonesia. In D. Kapchan (Ed.), Theorizing Sound Writing (pp. I9I-2I5). Wesleyan University Press.

Schafer, R. M. (1994). The Soundscape: Our Sonic Environment and the Tuning of the World. Destiny Books.

Siregar, S.N. (2020). Patronage Democracy in Indonesia. Journal of Indonesian Social Sciences and Humanities, Io (I), doi: Io.I4203/jissh.vioir.I58

Translated by M.A.S. Abdel (Ed.). (2008). The Qur'an. Oxford University Press.

Tsonka Al Bakri, M. M. and N. N. (20I9). Al Adhan: Documenting Historical Background, Practice Rules, and Musicological Features of the Muslim Call for Prayer in Hashemite Kingdom of Jordan. Musicologica Brunensia, 54(I67-I85).

Tuasikal, R. (20I4). Gereja ini Tak Bunyikan Lonceng dan Pasang Salib. kbr.id., retrieved from https://kbr.id/saga/II-20I4/gereja_ini_tak_ bunyikan_lonceng_dan_pasang_salib/35629. html, 8 November 2020

Wahid, A. (1982, February 20). Islam Kaset dan Kebisingannya. Tempo.

Weiner, I. (20I4). Religion Out Loud. Religious Sound, Public Space, and American Pluralism. New York University Press.

Widjojoatmodjo, R. . (I942). Islam in the Netherlands East Indies. The Far Eastern Quarterly, 2(I), 48-57.

Yampolsky, P. B. (2013). Music and Media in the Dutch East Indies: Gramophone Records and Radio in the Late Colonial Era, I903-I942. (Dissertation). University of Washington. 
